two objectives has received wide support from virtually every sector of the US scientific and political community. The main point of dispute, however, has been over appropriate procedures, and specifically the extent to which such activities should be tied to the policy directions of other institutions.

The administration has argued publicly that although ISTC will be conceived as part of an overall development assistance strategy, the existence of a council of advisers to the ISTC's director will provide sufficient autonomy; and, privately, that anything giving greater Third World involvement in decisionmaking - along the lines, for example, of Canada's International Development Research Center - would fail to gain Congressional support.

During last week's debate, the Senate rejected an amendment proposed by Senator Adlai Stevenson to increase the institute's autonomy by making the directors responsible to a board of directors. Although this proposal has been widely supported in the academic community, the administration claimed that it would weaken the links to other development efforts.

Supporters of the bill had spent considerable time putting their case against the Stevenson proposal. In doing so, it turned out that they had paid insufficient attention to the threat from the other direction, namely a growing conservative constituency in the Congress pledged to cut public expenditure and the federal bureaucracy.

These were the forces that provided support for an amendment from Senator Dennis Deconcini, a Democrat from Arizona, proposing that the legislation setting up the proposed ISTC be removed entirely from the International Development Assistance Act for 1980.

"At a time when the American people are themselves struggling to make ends meet, bescause of spiralling inflation and the beginnings of what promises to be a substantial recession, we can ill afford another well-intentioned but expensive agency to study and coordinate the problems which are all too depressingly familiar," Senator Deoncini said.

Although the funding requests associated with the institute were not great - the administration is initially asking for an additional $\$ 25$ million to support the institute's activities in the first year, most of its budget resulting from the transfer of research projects under way in the Agency for International Development (AID) - it would subsequently devour tax dollars at an ever-increasing rate, he said. If the new agency was a response to shortcomings in AID, then improvements should be made in AID, rather than creating a "whole new bureaucracy".

Senator Deconcini was joined by Senator Robert Dole of Kansas, who referred to reports appearing in the

national press that the United Nations currently holds a substantial amount of operating funds in low-interest bank deposits. "We do not need to solve another social problem by throwing more money at it - particularly at a time when similarly destined money is presently being wasted," he said.

Supporters of the administration proposal replied to such charges by claiming that the ISTC would considerably increase the effectiveness of US aid efforts. but in the end their arguments failed to carry sufficient weight; and the amendment rejecting the institute from the aid bill was agreed by 58 votes to $42-$ a margin which is said to have taken even the amendment's supporters by surprise.

"It was essentially a conservative vote, with people in the middle whose support we had previously been counting upon

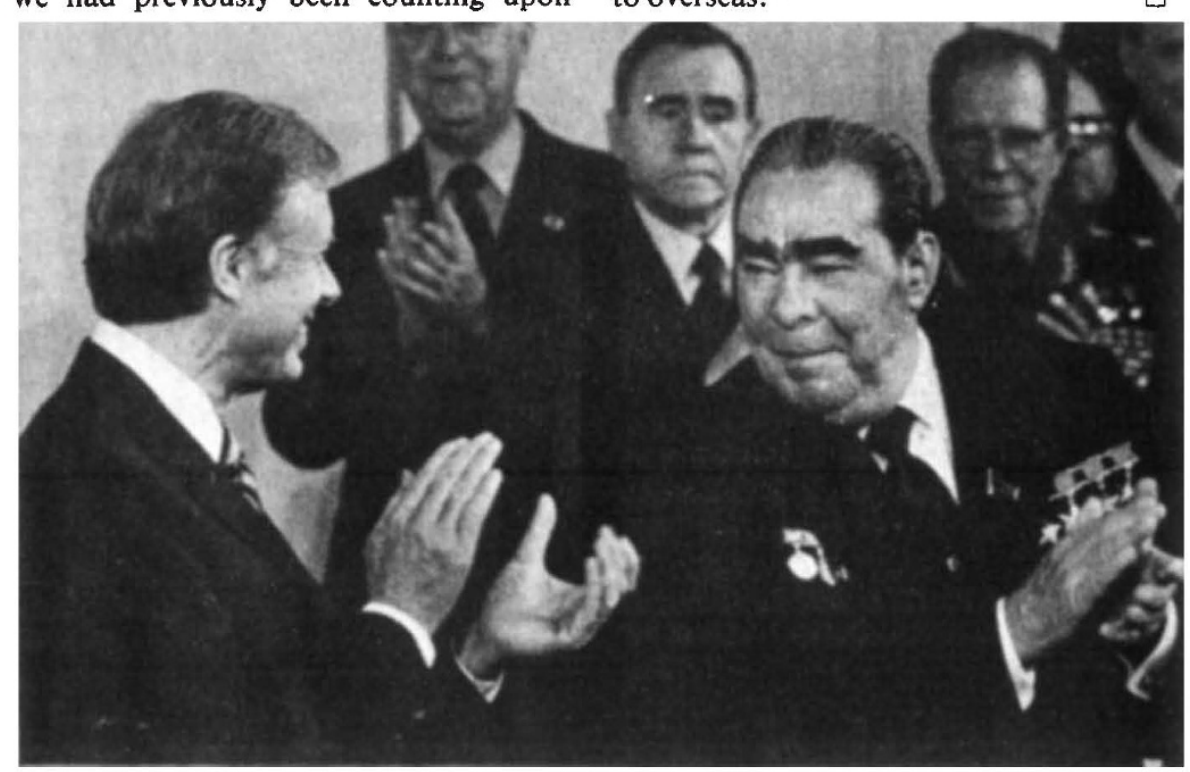

Mutual applause: Carter and Brezhnev after the SALT treaty

\title{
SALT warning on MX missiles decision
}

Although urging support for the Strategic Arms Limitation Treaty recently signed by President Carter and President. Brezhnev in Vienna, the Arms Control Association has warned that the benefits of the treaty will be undermined by the administration's decision to proceed with research and testing of a new generation of mobile missiles, known as MX.

In a statement released last week in Washington, the board of directors of the association say that, despite the closing of US intelligence bases in Iran, it considers the SALT II treaty to be adequately verifiable - a central issue of debate in the US Senate - and urges its ratification without substantive change.

However the ACA also expresses concern at the implications of the administration's recently announced plans to proceed with the design, development and deployment of the new MX missiles - possibly housed in and launched from underground trenches or arguing that the line on spending had to be drawn somewhere, and choosing this as the issue on which to do it," one administration official told Nature last week.

The precise fate of ISTC will not be known until representatives of the House and the Senate meet in the near tuture to negotiate over their differences on the foreign aid bill, in order to come up with a form that will be acceptable to both sides and can therefore be signed into law. The hope is that the conferees will agree to keep the institute in, possibly in return for cuts elsewhere.

But the restoration of funds is by no means certain. As one Washington lobbyist said last week: "Congress seems to have gone crazy this year in its desire to cut the budget; and the things that are easiest to cut are the things that are related to overseas.' from holes on a "shell-game" principle as a response to the increasing accuracy of Soviet weapons.

Criticising the lack of controls over increasing accuracy of ICBMs the ACA also says that "Deployment of more landbased, silo-destroying missiles will threaten nuclear stability and erode the basis of SALT still further if they are emplaced in mobile basing modes which multiply potential targets, forcing an adversary to programme additional warheads for targets which, in fact, contain no missiles."

The statement says that the problem of silo vulnerability is "largely hypothetical from an operational standpoint", and argues that deployment of the MX and similar systems by the USSR "will pose a far greater danger to American security, and to the SALT process and its accomplishments, than does the current prospect of a hypothetical Soviet attack on American land-based missiles." 